\title{
Hubungan Kebersihan Rongga Mulut dan Status Gingiva dengan Usia Kehamilan pada Ibu Hamil di Wilayah Kerja Puskesmas Sumbersari Kabupaten Jember
}

\section{(The Correlation of Oral Hygiene and Gingival Status with Gestational Age in Pregnant Women in the Working Area of Sumbersari Public Health Center Jember Regency)}

\author{
Nadiah Pujiati ${ }^{1}$, Kiswaluyo ${ }^{2}$, Masniari Novita ${ }^{3}$ \\ ${ }^{1}$ Fakultas Kedokteran Gigi Universitas Jember \\ 2Departemen IImu Kesehatan Gigi Masyarakat Fakultas Kedokteran gigi Universitas Jember \\ ${ }^{3}$ Departemen Biomedik Fakultas Kedokteran gigi Universitas Jember \\ Jalan Kalimantan No. 37 Kampus Tegalboto Jember \\ e-mail: nadiahpujiati.np@gmail.com
}

\begin{abstract}
Pregnancy causes the hormonal change which will improve the oral health of pregnant women. The hormonal change causes the gingiva to become more sensitive to toxins or irritants which causes inflammation of the gingiva. The Increasing gestational age gives the risk of pregnancy for periodontal tissue damage. This study aims to find out the correlation of oral hygiene and gingival status with gestational age in 97pregnant women in the working area of Sumbersari Health Center Jember Regency. The study was observational analytic using cross sectional study. The oral hygiene status of pregnant women was measured using the Oral Hygiene Index Simplified (OHI-S) and the gingival status measurement using the Gingival Index (Gl). The results showed that $73,2 \%$ oral hygiene status of pregnant women is moderate. All of the pregnant women in this study had gingivitis and most were moderate gingivitis. There was no correlation between oral hygiene with gestational age, but there was a correlation between gingival status and gestational age in pregnant women. The periodontal care should be obtained to prevent the gingival disease during pregnancy.
\end{abstract}

Keywords: Pregnant women, oral hygiene, gingival status

\begin{abstract}
Abstrak
Kehamilan mengakibatkan perubahan hormon yang akan mempengaruhi kesehatan rongga mulut ibu hamil. Perubahan hormon menyebabkan gingiva menjadi lebih sensitif terhadap toksin atau iritan yang mengakibatkan keradangan pada gingiva. Bertambahnya usia kehamilan berpengaruh secara signifikan terhadap kerusakan jaringan periodontal. Penelitian ini bertujuan untuk mengetahui hubungan kebersihan rongga mulut serta status gingiva dengan usia kehamilan pada 97 ibu hamil di wilayah kerja Puskesmas Sumbersari Kabupaten Jember. Penelitian ini merupakan observasional analitik dengan pendekatan cross sectional. Pemeriksaan kebersihan rongga mulut wanita hamil ditentukan menggunakan Oral Hygiene Index Simplified (OHI-S) dan pemeriksaan status gingiva menggunakan Gingival Index (GI). Hasil penelitian didapatkan bahwa $73,2 \%$ tingkat kebersihan rongga mulut ibu hamil adalah sedang. Seluruh ibu hamil dalam penelitian ini mengalami gingivitis dan sebagian besar adalah gingivitis sedang. tidak terdapat hubungan antara kebersihan rongga mulut dengan usia kehamilan, namun terdapat hubungan antara status gingiva dengan usia kehamilan pada ibu hamil. Perawatan periodontal perlu dilakukan untuk mencegah keparahan penyakit gingiva selama kehamilan.
\end{abstract}

Kata kunci: Ibu hamil, kebersihan rongga mulut, status gingiva 


\section{Pendahuluan}

Kehamilan merupakan suatu proses fisiologi yang menimbulkan perubahan pada tubuh wanita baik fisik maupun psikis. Perubahan-perubahan yang terjadi selama kehamilan yaitu pembesaran payudara, penambahan berat badan, lesu, lemas, morning sickness dan lainnya [1]. Kehamilan juga mengakibatkan terjadinya peningkatan sekresi hormon yang akan mempengaruhi kesehatan rongga mulut ibu hamil [2].

Bertambahnya usia kehamilan berpengaruh secara signifikan terhadap kerusakan jaringan periodontal. Adanya perubahan hormon saat kehamilan menyebabkan gingiva menjadi lebih sensitif terhadap toksin atau iritan lain seperti plak dan kalkulus yang mengakibatkan keradangan pada gingiva, selain itu terjadi perubahan pola makan dan kebiasaan tidak menjaga kebersihan rongga mulut pada sebagian ibu hamil akan meningkatkan risiko gingivitis yang dapat mempengaruhi kondisi kehamilan [3].

Hasil Riset Kesehatan Dasar (Riskesdas) tahun 2018 memperlihatkan prevalensi penduduk Jember yang bermasalah dengan gigi dan mulut sebesar $65 \%$ [4]. Gingivitis merupakan penyakit periodontal yang paling umum terjadi selama kehamilan, kejadian gingivitis terjadi $30-70 \%$ pada saat kehamilan [5]. Ibu hamil yang mengalami gingivitis berisiko melahirkan bayi berat badan lahir rendah kurang bulan dibandingkan dengan ibu hamil yang memiliki gingiva yang sehat [6].

Kebersihan rongga mulut adalah gambaran keadaan rongga mulut seseorang yang bebas dari debris, plak, dan kalkulus serta tidak tercium bau di dalam rongga mulut [7]. Kebersihan rongga mulut sangat penting untuk mengendalikan infeksi dari bakteri yang dapat mengakibatkan pengurangan aktivitas dan gejala penyakit [8].

Debris merupakan sisa makanan yang tertinggal pada permukaan gigi [9]. Kalkulus merupakan suatu masa yang mengalami kalsifikasi yang melekat erat pada permukaan gigi. Kalkulus dibedakan menjadi dua jenis berdasarkan lokasi dan hubungannya dengan margin gingiva yaitu kalkulus supragingiva dan kalkulus subgingiva [10].

Jaringan periondontal terdiri dari gingiva, ligamen periodontal, sementum dan tulang alveolar [7]. Gingiva merupakan salah satu jaringan lunak yang terdapat di rongga mulut yang melapisi dan melekat erat pada gigi dan tulang alveolar yang tersusun dari epitel berkeratin dan jaringan ikat. Ligamen periodontal adalah serat periodontal yang mengakibatkan gigi tertanam di dalam tulang alveolar dan mengisi diantara akar gigi dan tulang alveolar [11]. Sementum adalah bagian yang membentuk akar gigi, sementum termasuk jaringan periondontal karena menghubungkan gigi dengan tulang alveolar dan jaringan yang terdapat di selaput periodontal [12]. Tulang alveolar adalah bagian dari rahang tempat terletaknya akar-akar gigi yang mengikat gigi dalam suatu posisi relasi terhadap lainnya di dalam lingkaran gigi [11].

Proses kehamilan terjadi dengan adanya konsepsi. Konsepsi adalah bersatunya sel telur (ovum) dan sperma. Proses terjadinya kehamilan berlangsung kurang kebih sembilan bulan, dihitung mulai dari hari pertama menstruasi berakhir. Kehamilan dibagi menjadi tiga trimester yaitu trimester I, II dan III. Trimester I terjadi pada bulan kesatu sampai bulan ketiga kehamilan [1]. Trimester II terjadi pada bulan keempat sampai bulan keenam kehamilan [13]. Trimester III terjadi pada bulan ketujuh sampai bulan kesembilan [1].

Gingivitis merupakan kerusakan pada jaringan gingiva yang bersifat reversible yang diakibatkan oleh infeksi bakteri pada gingiva akibat dari mikroorganisme plak yang melepaskan produk-produk tertentu seperti kondroitin sulfatase, protease, hyaluronidase, dan kolagenase. Produk tersebut dapat menyebabkan kerusakan pada ruang interseluler dan memungkinkan bakteri atau produk bakteri tersebut mendapatkan akses ke jaringan ikat $[14,15]$.

Perkembangan gingivitis terjadi dalam empat tahap yang berbeda yaitu, tahap initial lesion, pada tahap ini tidak ada perubahan kecuali adanya eksudasi cairan dari sulkus 
gingiva. Tahap early lesion, secara klinis terdapat gingiva yang kemerahan dan mengalami perdarahan ketika dilakukan probing. Tahap established lesion, pada tahap ini terjadi perubahan klinis yang ditandai dengan warna kebiruan pada gingiva yang memerah karena gangguan aliran balik vena, kemudian terjadi inflamasi sedang hingga berat pada gingiva. Tahap advance lesion, tahap ini dikenal sebagai tahap lanjutan dari kerusakan periodontal, secara klinis dan mikroskopis terlihat perluasan lesi sampai ke tulang alveolar dan ligamen periodontal yang menyebabkan resorbsi tulang, pembentukan poket periodontal dan hilangnya kolagen secara berlanjut [14].

Gingivitis gravidarum merupakan manifestasi oral yang sering terjadi pada masa kehamilan. Gingivitis gravidarum terjadi karena peningkatan hormon estrogen dan progesterone. Gambaran klinis dari gingivitis gravidarum yaitu margin gingiva dan papilla interdental berwarna kemerahan, edema, permukaannya licin dan mengkilap, mudah berdarah dan disertai rasa sakit [16].

Puskesmas Sumbersari merupakan pelaksana teknis dari Dinas Kesehatan Kabupaten Jember untuk melaksanakan tugas-tugas operasional pembangunan kesehatan termasuk kesehatan gigi dan mulut. Kecamatan Sumbersari menjadi peringkat tertinggi dalam jumlah kunjungan ibu hamil ke fasilitas pelayanan kesehatan dengan jumlah kunjungan ibu hamil sebanyak 2.139 pada tahun 2018 [17].

Tujuan penelitian ini adalah untuk mengetahui hubungan kebersihan rongga mulut serta status gingiva dengan usia kehamilan pada ibu hamil di wilayah kerja Puskesmas Sumbersari Kabupaten Jember.

\section{Metode Penelitian}

Penelitian ini merupakan penelitian observasional analitik dengan pendekatan cross sectional. Teknik pengambilan sampel menggunakan accidental sampling dengan total subjek penelitian 97 responden. Penelitian ini dilaksanakan di wilayah kerja Puskesmas Sumbersari Kabupaten Jember pada bulan Januari-Februari 2020.
Populasi penelitian ini adalah ibu hamil yang berkunjung ke wilayah kerja Puskesmas Sumbersari yang terdiri dari Kelurahan Tegalgede, Kelurahan Antirogo, Kelurahan Wirolegi, Kelurahan Karangrejo dan Kelurahan Sumbersari. Pada ibu hamil dilakukan pencatatan usia ibu hamil dan usia kehamilannya. Selanjutnya dilakukan pemeriksaan status kebersihan rongga mulut menggunakan Oral Hygiene Index Simplified (OHI-S) dan status kesehatan gingiva menggunakan Gingival Index (GI). Data dilakukan uji normalitas KolmogorovSmirnov Test dan uji homogenitas Lavene Test dilanjutkan uji korelasi Pearson menggunakan SPSS.

\section{Hasil Penelitian}

Penelitian ini mengenai hubungan kebersihan rongga mulut serta status gingiva dengan usia kehamilan pada ibu hamil Sebanyak 97 wanita hamil dari lima kelurahan di wilayah kerja Puskesmas Sumbersari Kabupaten Jember (Tabel 1) mengikuti penelitian ini. Karakteristik responden dalam penelitian ini adalah lebih banyak pada usia kehamilan trimester II yaitu 46\%. (Tabel 2). Berdasarkan usia ibu hamil, paling banyak termasuk dalam kategori remaja akhir dan dewasa awal (Tabel 3).

Tabel 1 Distribusi Responden Berdasarkan Kelurahan

\begin{tabular}{lcc}
\hline \multicolumn{1}{c}{ Kelurahan } & $\begin{array}{c}\text { Jumlah } \\
(\mathrm{n})\end{array}$ & $\begin{array}{c}\text { Persentase } \\
(\%)\end{array}$ \\
\hline Kelurahan Sumbersari & 28 & 28,87 \\
Kelurahan Antirogo & 20 & 20,62 \\
Kelurahan Tegalgede & 16 & 16,49 \\
Kelurahan Wirolegi & 16 & 16,49 \\
Kelurahan Karangrejo & 17 & 17,53 \\
\hline Total & 97 & 100 \\
\hline
\end{tabular}

Tabel 2 Distribusi Responden berdasarkan Usia Kehamilan

\begin{tabular}{lcc}
\hline Usia Kehamilan & Jumlah $(\mathrm{n})$ & Persentase $(\%)$ \\
\hline Trimester I & 17 & 18 \\
Trimester II & 45 & 46 \\
Trimester III & 35 & 36 \\
\hline Total & 97 & 100 \\
\hline
\end{tabular}


Tabel 3. Distribusi Responden Berdasarkan Usia

\begin{tabular}{|c|c|c|c|}
\hline \\
\hline $\begin{array}{l}\text { Usia ibu } \\
\text { hamil }\end{array}$ & Kategori & $\begin{array}{c}\text { Jumlah } \\
\text { (n) }\end{array}$ & $\begin{array}{c}\text { Persentase } \\
(\%)\end{array}$ \\
\hline $12-16$ th & $\begin{array}{l}\text { Remaja } \\
\text { Awal }\end{array}$ & 4 & 4,12 \\
\hline $17-25$ th & $\begin{array}{l}\text { Remaja } \\
\text { Akhir }\end{array}$ & 42 & 43,30 \\
\hline $26-35$ th & $\begin{array}{l}\text { Dewasa } \\
\text { Awal }\end{array}$ & 43 & 44,33 \\
\hline $36-45$ th & $\begin{array}{l}\text { Dewasa } \\
\text { Akhir }\end{array}$ & 8 & 8,25 \\
\hline Total & & & 100 \\
\hline
\end{tabular}

Hasil penelitian didapatkan bahwa sebagian besar $(73,2 \%)$ tingkat kebersihan rongga mulut ibu hamil adalah sedang. Seluruh ibu hamil dalam penelitian ini mengalami gingivitis dan sebagian besar adalah gingivitis sedang (50,5\%) (Tabel 4 dan 5).

Tabel 4. Distribusi Responden Berdasarkan Kebersihan Rongga Mulut

\begin{tabular}{lcc}
\hline \multicolumn{1}{c}{ Kriteria OHI-S } & Jumlah $(\mathrm{n})$ & Persentase (\%) \\
\hline Baik & 10 & 10,3 \\
Sedang & 71 & 73,2 \\
Buruk & 16 & 16,5 \\
\hline Total & 97 & 100 \\
\hline
\end{tabular}

Tabel 5. Distribusi Responden Berdasarkan Status Gingiva

\begin{tabular}{lcc}
\hline Kriteria Gl & $\begin{array}{c}\text { Jumlah } \\
(\mathrm{n})\end{array}$ & $\begin{array}{c}\text { Persentase } \\
(\%)\end{array}$ \\
\hline Tidak ada keradangan & 0 & 0 \\
Keradangan ringan & 34 & 35,1 \\
Keradangan sedang & 49 & 50,5 \\
Keradangan berat & 14 & 14,4 \\
\hline Total & 97 & 100 \\
\hline
\end{tabular}

Berdasarkan usia kehamilan, status kebersihan rongga mulut ibu hamil trimester I terbanyak adalah sedang, demikian juga pada ibu hamil trimester II dan III. Status kesehatan gingiva ibu hamil trimester I yang terbanyak adalah keradangan ringan, sedangkan status kesehatan gingiva ibu hamil trimester II dan trimester III terbanyak adalah keradangan sedang (Tabel 6 dan 7).
Tabel 5 Distribusi Responden Berdasarkan Usia

\begin{tabular}{|c|c|c|c|}
\hline \multicolumn{4}{|c|}{ Ibu Hamil } \\
\hline $\begin{array}{l}\text { Usia ibu } \\
\text { hamil }\end{array}$ & Kategori & $\begin{array}{c}\text { Jumlah } \\
\text { (n) }\end{array}$ & $\begin{array}{c}\text { Persentase } \\
(\%)\end{array}$ \\
\hline $12-16$ th & $\begin{array}{l}\text { Remaja } \\
\text { Awal }\end{array}$ & 4 & 4,12 \\
\hline $17-25$ th & $\begin{array}{l}\text { Remaja } \\
\text { Akhir }\end{array}$ & 42 & 43,30 \\
\hline $26-35$ th & $\begin{array}{l}\text { Dewasa } \\
\text { Awal }\end{array}$ & 43 & 44,33 \\
\hline $36-45$ th & $\begin{array}{l}\text { Dewasa } \\
\text { Akhir }\end{array}$ & 8 & 8,25 \\
\hline Total & & & 100 \\
\hline
\end{tabular}

Tabel 6 Tabulasi Silang Kebersihan Rongga Mulut dengan Usia Kehamilan Oral Hygiene Index-Simplified

\begin{tabular}{|c|c|c|c|c|c|c|c|c|c|}
\hline \multirow{2}{*}{\multicolumn{2}{|c|}{$\begin{array}{c}\text { Usia } \\
\text { Kehamilan }\end{array}$}} & \multicolumn{8}{|c|}{$\begin{array}{l}\text { Oral Hygiene Index- Simplified } \\
\text { (OHIS) }\end{array}$} \\
\hline & & \multicolumn{2}{|c|}{ Baik } & \multicolumn{3}{|c|}{ Sedang } & \multicolumn{3}{|c|}{ Buruk } \\
\hline & & $\mathrm{n}$ & $\%$ & $\mathrm{n}$ & \multicolumn{2}{|c|}{$\%$} & $\mathrm{n}$ & \multicolumn{2}{|c|}{$\%$} \\
\hline \multicolumn{2}{|c|}{ Trimester I } & 1 & 5,88 & 14 & \multicolumn{2}{|c|}{82,35} & 2 & \multicolumn{2}{|c|}{11,76} \\
\hline \multicolumn{2}{|c|}{ Trimester II } & 5 & 11,1 & 32 & \multicolumn{2}{|c|}{71,11} & 8 & \multicolumn{2}{|c|}{17,78} \\
\hline \multicolumn{2}{|c|}{ Trimester III } & 4 & 11,4 & 25 & \multicolumn{2}{|c|}{71,43} & 6 & \multicolumn{2}{|c|}{17,14} \\
\hline \multicolumn{10}{|c|}{$\begin{array}{l}\text { Tabel 7. Tabulasi silang Status Gingiva dengan } \\
\text { Usia Kehamilan }\end{array}$} \\
\hline \multicolumn{10}{|c|}{ Gingival Index (GI) } \\
\hline \multirow[t]{2}{*}{$\begin{array}{l}\text { Usia } \\
\text { Kehamilan }\end{array}$} & \multicolumn{2}{|c|}{$\begin{array}{c}\text { Tidak } \\
\text { ada } \\
\text { Kerada } \\
\text { ngan }\end{array}$} & \multicolumn{2}{|c|}{$\begin{array}{c}\text { Kerada } \\
\text { ngan } \\
\text { Ringan }\end{array}$} & \multicolumn{2}{|c|}{$\begin{array}{c}\text { Keradang } \\
\text { an } \\
\text { Sedang }\end{array}$} & \multicolumn{3}{|c|}{$\begin{array}{c}\text { Kerada } \\
\text { ngan } \\
\text { Berat }\end{array}$} \\
\hline & $\mathrm{n}$ & $\%$ & $\mathrm{n}$ & $\%$ & $\mathrm{n}$ & $\%$ & & $\mathrm{n}$ & $\%$ \\
\hline Trimester & - & - & 10 & 59 & 7 & 41 & 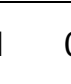 & 0 & 0 \\
\hline $\begin{array}{l}\text { Trimester } \\
\text { II }\end{array}$ & - & - & 14 & 31 & 25 & 56 & 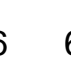 & 6 & 13 \\
\hline $\begin{array}{l}\text { Trimester } \\
\text { III }\end{array}$ & - & - & 10 & 29 & 17 & 49 & & 8 & 23 \\
\hline
\end{tabular}

Berdasarkan usia ibu hamil, seluruh ibu hamil usia remaja awal mempunyai status kebersihan rongga mulut sedang. Pada ibu hamil usia remaja akhir dan dewasa awal, status kebersihan rongga mulutnya sebagian besar adalah sedang, sedangkan pada ibu hamil usia dewasa akhir, status kebersihan rongga mulutnya sebagian besar adalah buruk (Tabel 8). 
Tabel 8 Status kebersihan rongga mulut pada ibu hamil dengan indeks OHI-S berdasarkan usia ibu hamil

\begin{tabular}{lcccccc}
\hline \multirow{2}{*}{$\begin{array}{l}\text { Kelompok usia } \\
\text { (Tahun) }\end{array}$} & \multicolumn{5}{c}{ Baik } & \multicolumn{3}{c}{ Sedang } & \multicolumn{3}{c}{ Buruk } \\
\cline { 2 - 7 } & $\mathrm{n}$ & $\%$ & $\mathrm{n}$ & $\%$ & $\mathrm{n}$ & $\%$ \\
\hline $\begin{array}{l}\text { Remaja Awal } \\
(12-16 \text { th) }\end{array}$ & 0 & 0 & 4 & 100 & 0 & 0 \\
$\begin{array}{l}\text { Remaja Akhir } \\
(17-25 \text { th) }\end{array}$ & 5 & 12 & 32 & 74 & 6 & 14 \\
$\begin{array}{l}\text { Dewasa Awal } \\
\text { (26-35 th) }\end{array}$ & 5 & 12 & 31 & 74 & 6 & 14 \\
$\begin{array}{l}\text { Dewasa Akhir } \\
\text { (36-45 th) }\end{array}$ & 1 & 13 & 3 & 38 & 4 & 50 \\
\hline
\end{tabular}

Tabel 9 Status gingiva pada ibu hamil dengan Gingival Index (Gl) berdasarkan usia ibu hamil

\begin{tabular}{|c|c|c|c|c|c|c|c|c|}
\hline \multirow{3}{*}{$\begin{array}{c}\text { Kelompok } \\
\text { usia } \\
\text { (Tahun) }\end{array}$} & \multicolumn{8}{|c|}{ Kriteria GI } \\
\hline & & $\begin{array}{l}\text { ak } \\
\text { a } \\
\text { da } \\
\text { an }\end{array}$ & & & & & & $\begin{array}{l}\text { ida } \\
\text { an } \\
\text { at }\end{array}$ \\
\hline & $\mathrm{n}$ & $\%$ & $\mathrm{n}$ & $\%$ & $\mathrm{n}$ & $\%$ & $\mathrm{n}$ & $\%$ \\
\hline
\end{tabular}

\begin{tabular}{lllllllll}
\hline Remaja & & & & & & & & \\
Awal (12- & & & & & & & & \\
16 th) & - & - & 3 & 75 & 1 & 25 & 0 & 0 \\
\hline Remaja & & & & & & & & \\
Akhir (17- & & & & & & & & \\
25 th) & - & - & 18 & 42 & 20 & 47 & 5 & 12 \\
\hline Dewasa & & & & & & & & \\
Awal (26- & & & & & & & & \\
35 th) & - & - & 13 & 31 & 23 & 55 & 6 & 14 \\
\hline Dewasa & & & & & & & & \\
Akhir (36- & & & & & & & & \\
45 th) & - & - & 2 & 25 & 4 & 50 & 2 & 25 \\
\hline
\end{tabular}

Sebagian besar status kesehatan gingiva pada ibu hamil usia remaja awal adalah keradangan ringan, sedangkan ibu hamil usia remaja akhir, dewasa awal dan dewasa akhir adalah keradangan sedang. 25 persen ibu hamil usia dewasa akhir menunjukkan keradangan berat (Tabel 9).

Hasil uji normalitas dan homogenitas diperoleh data homogen dan berdistribusi normal $(p>0,05)$. Hasil uji korelasi Pearson didapatkan adanya hubungan antara status kesehatan gingiva dengan usia kehamilan dengan nilai $r=0,296(p<0,05)$, akan tetapi tidak didapatkan hubungan antara status kebersihan rongga mulut dengan usia kehamilan $(p>0,05)$.

\section{Pembahasan}

Penelitian dilakukan pada ibu hamil trimester I, II dan III di wilayah kerja Puskesmas Sumbersari Kabupaten Jember. Tabel 1 menunjukkan sebagian besar ibu hamil berada pada Kelurahan Sumbersari, hal ini dikarenakan adanya perbedaan kepadatan jumlah penduduk pada lima kelurahan tersebut dan Kelurahan sumbersari merupakan kelurahan dengan jumlah penduduk perempuan terbanyak yaitu 19.535 jiwa [17].

Karakteristik responden penelitian berdasarkan usia kehamilan menunjukkan ibu hamil dengan usia kehamilan trimester II memiliki jumlah kunjungan tertinggi dan ibu hamil dengan usia kehamilan trimester I menunjukkan jumlah kunjungan terendah seperti terlihat pada Tabel 2. Hasil wawancara selama penelitian diperkirakan hal tersebut terjadi karena pada awal kehamilan ibu hamil tidak nyaman dengan kehamilannya. Hasil yang didapat pada penelitian ini sesuai dengan penelitian Hasim (2018) yaitu subjek terbanyak dalam penelitiannya merupakan ibu hamil trimester II dikarenakan pada trimester ini kecemasan yang dialami ibu hamil mulai berkurang dan ibu mulai mampu untuk melindungi dan menyediakan kebutuhan bagi janin [18].

Sebagian besar responden paling banyak terdapat pada usia 26-35 tahun seperti terlihat pada Tabel 5, berdasarkan wawancara selama penelitian, banyaknya usia ibu hamil yang dijumpai pada usia tersebut kemungkinan karena sebagian besar perempuan tidak terlalu cepat menikah. Hasil penelitian ini sesuai dengan penelitian Arina dkk [19] yaitu sebagian besar ibu hamil dijumpai pada usia 26-35 tahun. Banyaknya ibu hamil pada usia 26-35 dikarenakan usia tersebut merupakan masa produktif bagi perempuan [19].

Kelompok usia 12-16 tahun, 17-25 tahun maupun 26-35 tahun sebagian besar mempunyai status kebersihan rongga mulut sedang dan kelompok usia 36-45 tahun sebagian besar mempunyai status kebersihan rongga mulut buruk seperti terlihat pada Tabel 8. Hasil yang didapat sesuai dengan penelitian Anggraini dkk 
(2016) yang menunjukkan bahwa kelompok usia muda memiliki kebersihan rongga mulut yang lebih baik daripada kelompok usia lain [20]. Semakin bertambahnya usia maka status kebersihan rongga mulut akan semakin menurun. Peningkatan prevalensi akibat bertambahnya usia berhubungan dengan ketangkasan yang menurun dan ketangkasan yang terbatas menyebabkan kemampuan dalam pemeliharaan diri semakin berkurang [21].

Remaja awal sebagian besar mengalami keradangan ringan dan kelompok usia lainnya sebagian besar mengalami keradangan sedang seperti terlihat pada Tabel 9. Penelitian ini sesuai dengan Praharani dkk (2011) yaitu kelompok usia remaja awal paling banyak mengalami keradangan ringan sedangkan kelompok usia lainnya sebagian besar mengalami keradangan sedang. Kerusakan jaringan periodontal dimulai pada masa remaja awal. Angka prevalensi yang besar pada orang dewasa akhir dapat disebabkan oleh akumulasi dari penyakit yang sudah lama [21].

Ibu hamil sebagian besar memiliki kebersihan rongga mulut sedang seperti terlihat pada Tabel 3. Hasil yang didapat pada penelitian ini sesuai dengan penelitian Santoso dan Sutomo [22] yaitu kebersihan rongga mulut ibu hamil sebagian besar kategori sedang. Kehamilan menyebabkan perubahan dalam pemeliharaan kebersihan rongga mulut menjadi lebih buruk, hal ini disebabkan oleh timbulnya rasa mual, muntah, perasaan takut ketika menyikat gigi sehingga ibu malas untuk menyikat gigi [22].

Skor OHI-S trimester I mempunyai skor OHI-S baik lebih rendah dibandingkan trimester II dan III yang menunjukkan bahwa hanya sebagian kecil ibu hamil trimester I yang mempunyai kebersihan mulut yang baik, meskipun demikian kebersihan rongga mulut ibu hamil trimester I, II dan III termasuk ke kategori sedang seperti terlihat pada Tabel 6. Hasil penelitian ini sesuai dengan penelitian yang dilakukan oleh Wardhani (2012) yaitu rendahnya kebersihan rongga mulut yang baik terjadi karena ibu hamil mengalami morning sickness yang menyebabkan muntah, refluk dan mual yang dapat menghalangi praktik menjaga kebersihan rongga mulut rutin [23].

Tidak adanya hubungan kebersihan rongga mulut dengan usia kehamilan yang diperoleh pada penelitian ini mungkin dikarenakan kebersihan rongga mulut dipengaruhi oleh banyak faktor seperti pengetahuan, migrasi gigi, malposisi gigi, kontak proksimal tidak baik dan tidak ada kontak proksima. Faktor-faktor tersebut yang dapat memudahkan retensi plak [24].

Sebagian besar ibu hamil memiliki status gingiva sedang seperti terlihat pada Tabel 4. Hasil penelitian ini sesuai dengan Arina dkk [19] yaitu sebagian besar ibu hamil dengan status gingiva sedang, hal ini disebabkan oleh perubahan yang terjadi yaitu meningkatnya hormon estrogen dan progesteron [19]. Ibu hamil trimester I sebagian besar mengalami keradangan ringan dan ibu hamil trimester II dan III sebagian besar mengalami keradangan sedang seperti terlihat pada Tabel 7. Hasil penelitian ini sesuai dengan penelitian Arina dkk [19] yang menunjukkan bahwa sebagian besar ibu hamil mengalami keradangan ringan pada ibu hamil trimester I, keradangan sedang pada trimester II dan III.

Secara umum pada saat kehamilan terjadi perubahan yaitu meningkatnya hormon estrogen dan progesteron, hasil penelitian menunjukkan bahwa keradangan sedang lebih banyak ditemukan pada ibu hamil dengan usia kehamilan trimester II, hal ini dikarenakan pada saat proses fertilisasi sel telur dan implantasi sampai pengembangan plasenta, corpus luteum berperan atas peningkatan produksi progesteron dan estrogen dan kemudian plasenta mengambil alih peran corpus luteum dari trimester II dan terus meningkatkan produksi hormon seks wanita [25].

Peningkatan hormon estrogen dan hormon progesteron disertai hipervaskularisasi selama kehamilan dapat merangsang pembentukan prostaglandin dan menekan sel limfosit $\mathrm{T}$ sehingga terjadi peningkatan jumlah bakteri Prevotella intermedia yang menyebabkan terjadinya 
gingivitis, apabila ibu hamil sudah mengalami gingivitis sebelum kehamilan, maka pada usia kehamilan trimester I mulai terlihat tanda klinis gingivitis [3].

Hasil penelitian ini mendapatkan hubungan antara status gingiva dengan usia kehamilan. Hasil penelitian ini sesuai dengan penelitian Haryani dkk [5] yang menyatakan bahwa terdapat hubungan antara usia kehamilan dengan status gingiva, hal ini sesuai dengan teori yang menyebutkan bahwa selama kehamilan terjadi peningkatan jumlah hormon yang meningkat seiring bertambahnya usia kehamilan, sehingga semakin tua usia kehamilan maka gingiva menjadi lebih rentan terkena keradangan [5].

\section{Simpulan dan Saran}

Tidak terdapat hubungan antara kebersihan rongga mulut dengan usia kehamilan dan terdapat hubungan antara status gingiva dengan usia kehamilan pada ibu hamil di wilayah kerja Puskesmas Sumbersari Kabupaten Jember.

Perlu peningkatan kesadaran perilaku menjaga kebersihan rongga mulut yang lebih baik lagi untuk ibu hamil di wilayah kerja Puskesmas Sumbersari Kabupaten Jember serta perlu dilakukan penelitian lebih lanjut mengenai faktor-faktor lain yang dapat mempengaruhi kebersihan rongga mulut dan status gingiva.

\section{Daftar Pustaka}

[1] Kamariyah N, Anggasari Y, Muflihah S. Buku Ajar Kehamilan. Jakarta: Salemba Medika. 2014.

[2] Saputri D, Afrina A, Shalina RK. Perilaku Pemeliharaan Kesehatan Gigi dan Mulut Ibu Hamil di Wilayah Kerja Puskesmas Kopelma Darussalam Banda Aceh. Journal Of Syiah Kuala Dentistry Society. 2016; 1(1).

[3] Pradyanaputri K. Kusumadewi ES, Susanti DNA. Prevalensi Gingivitis pada Ibu Hamil Berdasarkan Usia Kehamilan, Pekerjaan, dan Pendidikan di RSUD Klungkung Tahun
2017. Odonto Dental Journal. 2018; 5 (2).

[4] Kementrian Kesehatan Republik Indonesia. Hasil Utama Riset Kesehatan Dasar 2018. Jakarta: Badan Penelitian dan Pengembangan Kesehatan. 2018.

[5] Haryani W, Winta N. Purwanti DE. Correlation of Pregnancy Stage and Gingivitis Status of Pregnant Woman who Visited RSUD Lebong Bengkulu. International Journal of Scientific Research and Education. 2018; 6 (7).

[6] Kasiha HE, Kawengian SES, Juliatri. Gambaran Tingkat Pengetahuan Ibu Hamil tentang Gingivitis di Puskesmas Kakaskasen Tomohon. Jurnal e-GiGi. 2017; 5 (2).

[7] Novita CF, Andriany P, Maghfirah SI. Hubungan Tingkat Pengetahuan lbu tentang Kebersihan Gigi dan Mulut dengan Tingkat Kebersihan Gigi dan Mulut Siswa SD Usia 10-12 Tahun. Journal Of Syiah Kuala Dentistry Society. 2016; 1(1).

[8] Lang NP, Lindhe J. Clinical Periodontology and Implant Dentistry. 6th ed. India: Spi Publisher Service. 2015.

[9] Cahyati WH. Konsumsi Pepaya (Carica Papaya) dalam Menurunkan Debris Index. Jurnal Kesehatan Masyarakat. 2013; 8 (2).

[10] Basuni C, Putri DKT. Gambaran Indeks Kebersihan Mulut Berdasarkan tingkat Pendidikan Masyarakat di Desa Guntung Ujung Kabupaten Banjar. Dentino Jurnal Kedokteran Gigi. 2014; 02 (1).

[11] Sariningsih E. Gigi Busuk dan Poket Periodontal sebagai Fokus Infeksi. Jakarta: PT Elex Media Komputindo. 2014.

[12] Scheid RC, Weiss G. Woelfel Anatomi Gigi. 8th. Jakarta : EGC. 2013.

[13] Ferry A, Angelina J. Bebas Sakit Gigi \& Mulut - Pentingnya Menjaga Kesehatan Gigi \& Mulut Selama Kehamilan. Ed. I. Yogyakarta: Rapha Publisher. 2018 
[14] Reddy S. Essentials of Clinical Periodontology and Periodontics. 3th ed. India: Jaypee Brothers Medical Publisher (P) Ltd. 2011

[15] Newman MG, Takei HH, Klokkevold PR, Carranza FA. Newman and Carranza's Clinical Periodontology. 13th ed. Canada: Elsevier Saunders. 2019.

[16] Soulissa AG. Hubungan Kehamilan dan Penyakit Periodontal. Jurnal PDGI. 2014; 63 (3).

[17] Badan Pusat Statistik Kabupaten Jember. Kabupaten Jember Dalam Angka Jember Regency In Figure 2019. Jember: Badan Pusat Statistik Kabupaten Jember. 2019.

[18] Hasim RP. Gambaran Kecemasan lbu Hamil. Skripsi. Surakarta: Universitas Muhammadiyah Surakarta. 2018

[19] Arina D. Saputri, dan C. F. Novita. Gambaran Status Gingiva Pada lbu Hamil Di Rumah Sakit Umum Merauxa Banda Aceh. Journal Caninus Dentistry. 2017; 02 (4).

[20] Anggraini CW, Wahyukundari MA, Pujiastuti P. Gambaran Status Kebersihan Rongga Mulut dan Status Gingiva Pasien RSGM Universitas Jember. E-Jurnal Kesehatan. 2016; 4 (3).
[21] Praharani D, Pujiastuti P, Ermawati T. Status Kebersihan dan Kesehatan Periodontal Pasien yang Datang Ke Klinik Periodonsia RSGM Universitas Jember Pe86riode Agustus 2009 Agustus 2010. Stomatognatic 2011; 8 (3).

[22] Santoso B, Sutomo B. Pengaruh Umur Kehamilan, Tingkat Pengetahuan Tentang Menyikat Gigi, terhadap Derajat Kebersihan Gigi dan Muliut pada Ibu Hamil di Kelurahan Bintaro Kabupaten Demak. Jurnal Kebidanan. 2017; 6 (3).

[23] Naseem M, Khurshid Z, Khan HA, Niazi F, Zohaib S, Zafar MS. Oral Health Challenges in Pregnant Women: Recommendation for Dental Care Professionals. The Saudi Journal for Dental Research. 2016; 7.

[24] Putri IN. Hubungan Kebersihan Mulut dengan Kesehatan Gingiva pada Mahasiswa Fakultas Kedokteran Gigi Universitas Jember yang Memakai Alat Ortodonti Cekat. Skripsi. Jember: Universitas Jember. 2019.

[25] Marla V, Srii R, Roy DK, Ajmera H. The Importance of Oral Health during Pregnancy: A review. Medical Express. 2018;002. 